\title{
Availability of ICT Facilities and Teachers' Competence in the Use of ICT among Public Secondary Schools in Ngara District, Tanzania
}

\author{
Faith Fidelis and Daniel Oduor Onyango, PhD \\ Saint Augustine University of Tanzania \\ Corresponding Mail: faithfidelis91@gmail.com
}

\begin{abstract}
This study sought to establish the availability of ICT facilities and teachers competence in the use of ICT among public secondary schools in Ngara, Tanzania. The study employed a mixed research approach in that interview schedule and questionnaire were employed as sources of data. The population of the study was 525 stakeholders from 31 secondary schools, including the DEO, the WEO, the Heads of schools, ICT manager and teachers. Simple random sampling and purposive sampling were used to determine the sample of 84 respondents from four randomly selected schools. Qualitative data was analyzed based on themes while quantitative data was analyzed descriptively. The study revealed that the schools faced non availability of ICT facilities and internet connection. They also faced limited electricity supply and limited funds for maintenance of facilities. Furthermore, a significant number of teachers did not have competence in any of the aspects of computer. Very few could use internet while another few had some competence in hardware and programming. Therefore, it was recommended that the government and other education stakeholders should organize for seminars and workshop for capacity building so that teachers may gain knowledge and competence in the use of ICT facilities. The Ministry of Education should allocate funds for buying ICT facilities and devices and for maintenances.
\end{abstract}

Keywords: ICT facilities, teachers' competence, ICT, secondary school, digital divide

\section{Introduction}

The rapid global technological advancement and economic development place a great investment into education because information and technology have been developing very quickly in recent years and have opened new directions in the area of education. Therefore, education has to go with technological changes to cope with the current world changes. Educational system has felt the impact and influence of information and communication technology which has become a crucial factor for most organizations and business nowadays. The emergence of ICT has caused many education reforms (Zhang and Aikman, 2007). As a result, ICT enhances day to day management in organizations and enables schools to improve their efficiency and cope with the rapid changing world (Ngeze, 2017).

Tapera and Kujeke (2019) defined information and communication technology as a type of technology that supports activities involving information, such as gathering, processing, storing and presenting data. In school setting, for example, ICT can be used to store information such as financial records and transactions and to teach. Khan, Khan, Din, Ismail, Khattak and Jan (2015) stated that ICT refers to technologies that provide access to information through communication devices which may include computers, scanners, printers and internet connection. Likewise, Ufuophu and Ayobami (2012) assert that ICT includes internet, cable data transmission and computer equipment. Wanjiru (2013) asserts that technology is a term that includes any communication devices or application including cellular phones, television, radio, computers and network hardware and software.

According to Ashrafi and Murtaza (2008), modern technology includes products and services such as desktop, computers, laptop, hand-held devices, wired or wireless connectivity, business productivity software, data storage and security, network security and other related protocols. Therefore, information and communication technology may be defined as any kind of technology that is used to facilitate various activities whether in institution or 
individually. These activities include communication, data recording and data keeping. The use of ICT plays a very important role in teaching and learning. Tearle (2004) argues that there is a need for schools to have a vision for technology as an agent of change.

Oyier, Odundo, Ganira and Wangui, (2015) said that the uses of ICT enables schools to achieve improvement. In addition to that, Hare (2007) argues that the use of ICT for effective management of secondary schools has led to increase in efficiency and optimal resource utilization. Selwood (2005) argues that the use of ICT in the management of educational institutions is very helpful to ensure management duties are well performed to the maximum. JISC report (2012) listed nine main uses of ICT in education system; one of them is financial management. This suggests that ICT use is essential for effective implementation of school goals and objectives. This study was therefore guided by two objectives: 1) to establish the availability of ICT facilities in schools under investigation and (2) to establish the competence of teachers on ICT skills.

\section{Literature Review}

The researcher reviewed various literatures to explore more about teachers' competence in ICT and the availability of ICT facilities in schools.

\section{Availability and the Use of ICT Facilities}

Nikolopoulou and Gialamas (2015) conducted a study in Greece on barriers to ICT use in high schools. The findings show that lack of internet access was among the major barriers to the use of computers in high schools. This suggests a possibility of a school having computers without having access to internet due to the digital divide related issues.

Gadzama (2019) did a study on the successful integration of ICT in teaching and learning among public secondary schools in Nigeria. The study revealed that non availability of software and hardware infrastructure is a major factor challenging the utilization and integration of computer and ICT in the schools. The study also showed that not all public secondary schools across the Adamawa State had been equipped with computers and ICT resources. This is to say, with the absence of software and hardware issues, teachers could not integrate the ICT effectively, as to integrate the ICT effectively, there should be essential software and hardware facilities in schools.
Nwasinachi and Bernadette (2014) conducted a study on assessment and prospective application of information and communication technology among secondary school teachers in Enugu Urban, Nigeria; the findings show that ICT facilities were not fully available in many schools. This hindered the adoption of ICT in teaching and learning. That means to integrate the ICT effectively, there should be available ICT facilities including software and hardware connections.

Furthermore, Asabere (2017) conducted a study on an ICT model for integrating teaching, learning and research in a technical university education in Ghana. The findings revealed that the integrating ICT in education was quite difficult due to poor wireless connectivity.

In Kenya, The study by Mingaine (2013) on challenges in the implementation of ICT in public secondary schools found that high cost of acquisition and maintenance of ICT equipment was a barrier that had hindered the adoption and the integration of ICT. Particularly, the study found that lack of stable electricity is a serious problem in the implementation of ICT integration in schools.

In Tanzania, Ngeze (2017) did a study on ICT integration in teaching and learning among 220 secondary school teachers selected from 32 schools. The study established that schools did not have enough ICT devices for effective integration of ICT. The study by Ngimi (2013) on opportunities and challenges of integrating ICTs in education delivery at the Open University of Tanzania revealed that inadequate ICT infrastructure is one of the challenges for a successful integration of ICT. Thus in order to integrate effectively, there must be good infrastructure such as software devices, hard ware devices, internet connectivity and power.

Minja (2015) did a study on the contribution of the Information and Communication Technology on service delivery in secondary schools in Tanzania, and the study revealed that irregular power supply, high cost in purchasing computers and lack of funds are the major challenges facing the application of ICT in school. Therefore, in order to integrate effectively, there must be good infrastructure such as software devices, hard ware devices and internet access. Ndibalema (2014) further reported that many teachers in secondary schools do not have sufficient knowledge and skills on the use of ICT in teaching and learning. Therefore, this study sought to establish the availability of ICT facilities and 
teachers' competence in the use of ICT among Public Secondary Schools in Ngara, Tanzania.

\section{Teachers' Competence in the Use of ICT}

Tezci (2010) conducted a study among the Turkish teachers on the attitude and knowledge level, using a questionnaire as data collection tool and revealed that teachers' level of knowledge was low. Few teachers knew how to use the internet, email, word processing, graphics and presentation software.

Furthermore, the study of Sotashe (2007) in South Africa on the challenges faced by secondary school teachers in integrating ICT into the curriculum. The study adopted interview and questionnaire as the data collection tools. The findings show that teachers lacked knowledge as far as the integration of ICT is concerned. Particularly, teachers lacked appropriate ICT integration skills.

Muniandi and Singh (2012) conducted a study on the factors affecting school administrators' choices in adopting ICT tools in Malaysia. The data collection tools for this study included interview and observation. The findings show that among 134 teachers who were sampled, most of them had learnt how to use the various hardware and software independently. This is to say, these teachers had gained skills on how to use computers and they could probably be able to integrate ICT successfully in teaching and learning.

Adeoye (2013) conducted a study on appraising the role of information and communication technology as a change agent for higher education in Nigeria. The study adopted the descriptive survey research design and structured questionnaires were used as a data collection tool. The study found out that there was inadequate number of teachers trained on how to use the ICT in teaching.
Tedla (2012) conducted a study on the importance, impact and barriers of ICT in teaching and learning in East African countries. The study used observation, empirical literature review and focus group discussion as the sources for data. The study found that most of the informants in the focus group discussion had never received training on how to use computers in teaching. The study concluded that teachers require ICT training both at pre- service and in-service levels. Otherwise, without the proper knowledge, the integration would be impossible.

The study of Emmanuel and Eze (2012) in Ghana used the descriptive survey design and questionnaire was used as a data collection tool. The study revealed that many teachers lacked knowledge about the use of computers. Majority of respondents did not have any training in the use of ICT (computers) before they joined the teaching profession.

In Tanzania, the study of Kayombo and Mlyakado (2016) established a need for teachers to be trained on how to use the ICT facilities.

\section{Research Methodology}

The study used a mixed -method approach. According to Hanson, Magnusson and Borg (2004), mixed approach involves the collection and analysis of both qualitative and quantitative data in a single study. The researchers used this approach to obtain quantifiable and non-quantifiable information associated with the problem under investigation.

\section{Research Design}

This study employed the descriptive survey design which provides information about people's attitudes and opinions (Orodho \& Kombo 2002).

Table 1: Distribution of sample size

\begin{tabular}{lccc}
\hline Category & Targeted Population & Technique & Sample Size \\
\hline DEO & 1 & Purposive & 1 \\
ICT Manager & 1 & Purposive & 1 \\
WEO & 22 & Purposive & 3 \\
Heads of School & 31 & Purposive & 4 \\
Teachers & 470 & Simple Random & 75 \\
Total & $\mathbf{5 2 5}$ & & $\mathbf{8 4}$ \\
\hline
\end{tabular}

\section{Population and Sampling}

According to Cooper (1998), population of the study has to do with those individuals or groups the researcher hopes to include in the study. The population of the study was 525 stakeholders from 31 secondary schools, including the DEO, the WEO,
Heads of schools, ICT manager and teachers. Simple random sampling and purposive sampling were used to determine the sample of 84 respondents from four randomly selected schools. Qualitative data was analyzed based on themes while quantitative data was analyzed descriptively. as 
reflected in table 1 . The researchers employed the simple random and purposive sampling techniques to determine the sample of 84 respondents including 75 teachers from four randomly selected schools, one DEO, one ICT Manager, three WEOs and 4 heads of schools. The purposive sampling was used for the District Education Officer, the ICT Manager, Ward Educational Officers and heads of schools who provided in-depth information for the study.

\section{Statistical Treatment of Data}

This study employed quantitative and qualitative techniques. The quantitative and qualitative data was analyzed through descriptive statistics and according to the themes that emerged, respectively.

\section{Ethical Considerations}

Creswell (2012) asserts that respondents should be protected by keeping the information provided confidential. The researchers observed the informed consent in that only those interested were given chance to participate. With that regard, the names of sampled schools and respondents were kept anonymous.

\section{Validity and Reliability}

To ensure that the tools were valid and reliable, experts from the Department of Education Foundations at the Saint Augustine University of Tanzania examined the content of the research tools. As Creswell (2012) defines reliability as a situation whereby scores from an instrument are stable and consistent, test-retest procedure was applied to the same group at a certain interval. The reliability coefficient was greater than 07 .

\section{Findings and Discussion}

This section was guided by two objectives of the study: (1) to establish the availability of ICT facilities in schools under investigation and (2) to establish the competence of teachers on computer skills.

\section{Availability of ICT facilities in Schools}

The first objective was to establish the availability of ICT facilities in schools under investigation..

Table 2: Availability of ICT Facilities in schools

\begin{tabular}{lccccc}
\hline \multicolumn{1}{c}{ Item in the Questionnaire } & YES & f & NO & \% \\
\hline Availability of ICT facilities/ devices & 36 & 48 & 39 & 52 \\
Strong internet access & 24 & 32 & 51 & 68 \\
Stable electricity & 36 & 48 & 39 & 52 \\
Funds for maintenance & 36 & 48 & 39 & 52 \\
\hline
\end{tabular}

The researchers used the YES/ NO options for respondents to indicate the availability of ICT facilities in their schools.

Table 2 indicates that majority of respondents indicated non availability of ICT facilities, strong internet connection, stable electricity and funds for maintenance. This suggests that ICT facilities are not sufficient for teachers in schools under investigation.

The interview schedule throws more light on the non-availability of ICT facilities. One of the school heads, for instance, revealed that "in my school, while we try to make sure there are all needed facilities and devices for teaching and learning like computers and photocopy machines, it is not easy to buy these things because we don't have enough funds." Another respondent said:

Adoption of ICT for sure demands good ICT facilities and devices. We lack good facilities and devices as we have few computers to use and when they get broken, we don't have any alternative. Not only computers but also other devices like modem, when all these collapse, it is very difficult to continue with our activities.

On the same matter, one more respondent had this to say:
We don't have even computer laboratories. We don't have our own computers in offices either. We don't have good ICT facilities and devices, thus it's very hard to adopt ICT as the adoption depends on the availability of facilities and devices and how we interact with them. Lack of these causes the ineffectiveness in the use of ICT.

Internet access also emerged as a strong theme during the interview. It was revealed that the schools whose heads participated in this study, did not have strong internet access. One of the school heads who participated stated: 
We don't have access to internet at our school. If you want to search various teaching and learning content online, you must travel to town so as to access strong internet access. One needs to go more than $21 \mathrm{~km}$ to get an internet access.

This implies that lack of funds is a major factor that hindered the availability of ICT facilities in schools under investigation. The lack of ICT facilities hinders effective teaching and learning. This was revealed by one of respondents who said that they fail to adopt ICT in teaching and learning due to inadequate ICT facilities and devices to be used: "It's hard to adopt ICT in teaching and learning due to inadequate ICT facilities and devices. We have two desktops here at our school, which are used by the headmaster, second master and the academic master." As such, they are used by school administrators for administrative purposes, it is difficulty for teachers and students to access the ICT facilities for teaching and learning purposes. The findings further shows that lack of facilities is one of the factors that may cause the adoption of ICT in teaching and learning to be difficult as teachers fail to adopt the ICT because they don't have facilities to use. This was further indicated by another respondent:
The presence of ICT facilities and devices is very important in the adoption of ICT in schools. Without these facilities and devices, adoption cannot be successful. We, teachers fail to adopt ICT effectively due to inadequate ICT facilities and devices. How could we adopt ICT while we don't have facilities and devices?

When the school lacks these facilities and devices, the adoption becomes difficult. Thus, teachers will still use traditional teaching and learning methods instead of using modern technologies. Therefore, findings suggest that lack of strong internet access causes the adoption of ICT in school to be difficult. This is similar to the findings of Nikolopoulou and Gialamas (2015) in Greece who identifies that lack of internet access was among the perceived barrier to the use of computer in schools.

\section{Teacher's Competence in Computer}

The second objective of this study was to establish the competence of teachers on computer skills. Table 3 shows the extent to which teachers had competence in various ICT aspects. Teachers were asked to tick one item to which they were most competent.

Table 3: Teacher's Competence in Computer

\begin{tabular}{lcc} 
& Table 3: Teacher's Competence in Computer \\
\hline Computer Skills & Frequency & Percent \\
\hline Programming & 1 & 1 \\
Internet & 12 & 15 \\
Email & 19 & 25 \\
Typing & 12 & 15 \\
Operating system & 2 & 3 \\
Word processing & 1 & 1 \\
Hardware & 3 & 4 \\
Data base & 1 & 1 \\
None & 25 & 33 \\
Total & $\mathbf{7 5}$ & $\mathbf{1 0 0 . 0}$ \\
\hline
\end{tabular}

Table 3 indicates that 25 (33\%) of teachers did not have competence in any of the aspects of computer, $19(25 \%)$ indicated to have competence in the use of email while only 12 (15\%) would type. The table also indicates that only $12(15 \%)$ could use internet while only $3(4 \%)$ had some competence in hardware. One (1\%) had competence in programming, $1(1 \%)$ in word processing and $1(1 \%)$ in data base. The findings indicate that there is low capacity (knowledge/skills) of teachers in ICT usage. This finding is in harmony with that of Tezci (2010) who revealed that teachers' level of knowledge in
ICT in Turkey is still low as few of them are able to use internet, e-mail, word processing and graphics.

\section{Conclusions and Recommendations}

This part presents the conclusions and then gives the recommendations of the study.

\section{Conclusions}

The study concludes that the schools faced non availability of ICT facilities and internet connection. They also faced limited electricity supply and funds for maintenance. Computer laboratories were 
missing, and teachers did not have their personal computers, thus, it was not easy to integrate the ICT. As such, teachers were forced to use traditional teaching and learning approaches. Therefore, lack of ICT facilities and internet access caused the adoption of ICT in school to be difficult.

A significant number of teachers did not have competence in any of the aspects of computer. Very few could use internet while another few had some competence in hardware and programming. Therefore, there was low capacity in terms of knowledge and skills for teachers to integrate the ICT in the teaching and learning process.

\section{Recommendations}

The researchers recommend that school leaders should organize for seminars and workshop for capacity building for teachers to gain competence in the use of ICT facilities for teaching and learning. Furthermore, the Ministry of Education should allocate funds for buying ICT facilities and devices, and for maintenances. The government through the Rural Electricity Authority should accelerate the distribution of electricity in rural areas so that schools should have access to electricity, a major factor for effective integration of ICT.

\section{Reference}

Adeoye, M.Y. (2013). Role of Information, Communication Technology (ICT) as a change Agent for Higher Education in Nigeria. International Journal of Educational Administration and Policy Studies, 5 (8), 177-183. Retrieved from https://eric. ed.g ov/?id=EJ1084266.

Asabere, N. Y. (2017). AIDS: An ICT Model for Integrating Teaching, Learning and Research in Technical University Education in Ghana. The International Journal of Education and Development using Information and Communication Technology (IJEDICT), 13(3), 162-183. Retrieved from https://www.researchgate.net.

Ashrafi, R., \& Murtaza, M. (2008). Use and Impact of ICT on SMEs in Oman: The Electronic Journal Information Systems Evaluation, 11(2), 125138. Retrieved from www.researchg ate.net/publication/228526881_use_and_i mpacts.

Cresswell, J. (2012). Educational Research: Planning, Conducting and Evaluating Qualitative and Quantitative Research (4 ${ }^{\text {th }}$ ed.), Boston: Pearson Education Inc.
Cooper, H. (1998). The Happy Personality: A Metaanalysis of 137 Personality Traits and Subjective Well- being. Psychological Bullet-in, 124(21),197-229. Retrieved from https://doi.org/10.1037/0033- 2909.

Emmanuel, A., \& Eze, I. (2012). Utilization of ICT in Education for Sustainable Development. Conference on E-learning in Corporate, Government, Healthcare and Higher Education Las Vegas USA. Retrieved from https:// www.researchgate.net.

Gadzama, A. W. (2019). Utilization of ICT and Technology Transfer: A Panacea to Nigeria's Economic Development. IJESC, 9 (9), 23687-23692. Retrieved from https://ijesc.org/

Hanson, E., Magnusson, L., \& Borg, M. (2004). A Literature Review Study of Information Communication Technology as a Support for Frail Older People Living at Home and their Family Carers. Technology and Disability, 16 (4), 223-235. DOI: 3233/TAD-2004-16404.

Hare, H. (2007). ICT in education in Tanzania, survey of ICT and education in Africa; Tanzania country report.

JISC Report. (2012). ICT and General Administration in Educational Institutions. Policy Brief. Retrieved fromhttps://iite.unes co.org $>$ files $>$ pdf.

Kayombo, J., \& Mlyakado, P.B. (2016). The Paradox of ICT Integration in Secondary Education in Tanzania: Assessment of Teachers' ICT Knowledge and Skills in Tanga and Mwanza Regions. International Journal of Research Studies in Educational Technology, 5 (1), 17-27. DOI:10.5861/ijr set.201 5. 1299.

Khan, S. M., Khan, I., Din, S., Ismail, M.H., Khattak, R., \& Jan, R. (2015). The Impacts of ICT on the Students' Performance: A Review of Access to Information. Research on Humanities and Social Sciences, ISSN 22245766. Retrieved from www.iiste.org.

Mingaine, L. (2013). Leadership Challenges in the Implementation of ICT in Public Secondary Schools, Kenya. Journal of Education and Learning, 2 (1). DOI: 10.5539/JEL.v2n/p32.

Minja, E. S. (2015). Contribution of Information and Communication Technology (ICT) on Service

39 East African Journal of Education and Social Sciences (EAJESS) 2(2)34-40 
Delivery in Secondary Schools in Tanzania: A Case Study of Karatu Council (Masters Distertation, Mzumbe University). Retrieved from www.scholar.mzumbe.ac.tz.

Muniandi, K., \& Singh, R. T. (2012). Factors Affecting School Administration Choices in Adopting ICT in Schools: The Case of Malaysian Schools. International Journal Education Studies, 5 (4). DOI: $\quad 10.5539 / \mathrm{je} \quad$ s.v5n $4 / \mathrm{p} 21$.

Ndibalema, P. (2014). Teachers' altitude towards the use of information communication technology (ICT) as a pedagogy tool in secondary schools in Tanzania; the case of Kondoa district. International journal of education and research, 2(2), 115128.

Ngeze, L. (2017). ICT Integration in Teaching and Learning in secondary schools in Tanzania: Readiness and way forward; International Journal of Information and Education 7(6), 424-427.

Ngimi, H. M. (2013). Opportunities and Challenges of Intergarting ICTs in Eduation Delivery in the Institute of Continuing Education at the Open University of Tanzania (Masters Dissertation, The Open University of Tanzania). Retrieved from https:// repository. out.ac.tz/1049/.

Nikolopoulou, K., \& Gialamas, V. (2015). Barriers to ICT use in High Schools: Greek Teachers'

Perceptions. Journal of Computers in Education, 3 (1), 59-75. DOI: 10.1007/540692-015-0052-Z.

Nwasinachi, M.U., \& Bernadette, U. M. (2014). Assessment and Prospective Application of Information and Communication Technology Usage among Secondary School Teachers in Enugu, Urban, Nigeria. Journal of Education, Society and Behavioral Science, 336-3349. DOI: 10.9734/BJESBS/2014/5841.

Orodho, A. J., \& Kombo, D. K. (2002). Research Methods. Nairobi: Kenyatta University. Institute of Open learning Kenya.

Oyier, C.R., Odundo, P.A., Ganira, L., \& Wangui, L. (2015). Effects of ICT integration in management of Private Secondary Schools in Nairobi Country, Kenya: Policy options and Practices. World Journal of Education 5, (6), 213-219.
Selwood, I. (2005). Teacher workload: using ICT to release time to teach, Educational Review, 57(2), 163- 174. DOI: 10.10 80/0013 191042000308341.

Sotashe, M.N. (2007). Challenges Faced by Secondary School Head Teachers in Integrating ICT into the Curriculum: A Multiple Case Study in the Grahams town Circuit.

Tapera, M., \& Kujeke, C. (2019). Information and communication technology (ICT) challenges in teaching chemistry. A case study of Zimbabwean Polytechnics. International journal of advanced research and innovative ideas in education .5 (1), 23954396.

Tearle, P. (2004). A Theoretical and Instrumental framework for implementing change in the context of ICT in education. Cambridge Journal of Education 34(3), 331-351.

Tedla, B. (2012). Understanding the Importance, Impacts and Barriers of ICT on Teaching and Learning in East African Countries. International Journal on E-learning. DOI: 10. 20533/IJELS.2046.4568.2012.0025

Tezci, E. (2010). Attitudes and Knowledge Level of Teachers in ICT Use: The Case of Turkish Teachers. Journal of Human Science, 7 (2). Retrieved from https://www.ins anbili mleri.com/en.

Ufuophu, E., \& Ayobami, O. (2012). Usage of information and communication technologies and job motivation among newspaper workers in Nigeria. Journal of communication and media research 4(1), 89-92.

Wanjiru, K.R. (2013). The Use of Onformation and Communication Technology in Improving Teaching and Learning in Public Primary Schools in Gatanga District, Muranga County, Kenya. (Masters Dissertation, University of Nairobi). Retrieved from https://erepo sitory. uonbi.ac.ke

Zhang, P., \& Aikman, S. (2007). Attitudes in ICT Acceptance and Use, Proceedings of the International Conference on Human Computer Interaction, Beijing. 